\title{
Kinetics and Mechanisms of Virus Inactivation by Chlorine Dioxide in Water Treatment: A Review
}

\author{
Yuexian $\mathrm{Ge}^{1} \cdot$ Xinran Zhang ${ }^{1} \cdot$ Longfei Shu $^{1} \cdot$ Xin Yang $^{1}$ (D)
}

Received: 26 May 2020 / Accepted: 1 February 2021 / Published online: 25 February 2021

(c) The Author(s), under exclusive licence to Springer Science+Business Media, LLC part of Springer Nature 2021

\begin{abstract}
Chlorine dioxide $\left(\mathrm{ClO}_{2}\right)$, an alternative disinfectant to chlorine, has been widely applied in water and wastewater disinfection. This paper aims at presenting an overview of the inactivation kinetics and mechanisms of $\mathrm{ClO}_{2}$ with viruses. The inactivation efficiencies vary greatly among different virus species. The inactivation rates for different serotypes within a family of viruses can differ by over $284 \%$. Generally, to achieve a 4-log removal, the exposure doses, also being referred to as $\mathrm{Ct}$ values (mutiplying the concentration of $\mathrm{ClO}_{2}$ and contact time) vary in the range of $0.06-10 \mathrm{mg} \mathrm{L}^{-1} \mathrm{~min}$. Inactivation kinetics of viruses show two phases: an initial rapid inactivation phase followed by a tailing phase. Inactivation rates of viruses increase as $\mathrm{pH}$ or temperature increases, but show different trends with increasing concentrations of dissolved organic matter (DOM). Both damages in viral proteins and in the $5^{\prime}$ noncoding region within the genome contribute to virus inactivation upon $\mathrm{ClO}_{2}$ disinfection.
\end{abstract}

Keywords Chlorine dioxide $\left(\mathrm{ClO}_{2}\right) \cdot$ Virus $\cdot$ Disinfection $\cdot$ Kinetics $\cdot$ Mechanisms $\cdot$ Water treatment

Chlorine dioxide $\left(\mathrm{ClO}_{2}\right)$, an alternative disinfectant to chlorine, has been widely used to control a number of waterborne pathogens in water and wastewater treatment (AWWA Water Quality Division 2000; Sobsey 1989). Compared with chlorine, $\mathrm{ClO}_{2}$ greatly reduces the generation of toxic halogenated disinfection products (Chang et al. 2000; Korn et al. 2002; Zhong et al. 2019), and chlorite and chlorate are the major $\mathrm{ClO}_{2}$ byproducts (Gan et al. 2020; Schmidt et al. 2000; Sorlini et al. 2014). $\mathrm{ClO}_{2}$ has a superior inactivation ability on bacteria such as Escherichia coli and Staphylococcus aureus (Huang et al. 1996), viruses such as poliovirus and adenovirus (Huang et al. 1997), fungi such as Penicillium chrysogenum and Stachybotrys chartarum (Wilson et al. 2005) and protists such as Cryptosporidium parvum (Chauret et al. 2001; Korich et al. 1990) and Giardia intestinalis (Winiecka-Krusnell and Linder 1998). Among these microorganisms, viruses consist of relatively simple structures and lack mechanisms to repair oxidative damage

Xin Yang

yangx36@mail.sysu.edu.cn

1 School of Environmental Science and Engineering, Guangdong Provincial Key Laboratory of Environmental Pollution Control and Remediation Technology, Sun Yat-Sen University, Guangzhou 510275, China outside the hosts (Choe et al. 2015; Wigginton and Boehm 2020). However, viruses remain a concern as they exhibit higher resistance toward disinfectants than traditional bacterial indicators such as Escherichia coli and Enterococci and have very low infectious doses (Aronino et al. 2009; Fulton and Budd 1992; Mamane et al. 2007). The United States Environmental Protection Agency (USEPA) (2018) has included adenovirus, caliciviruses, enterovirus, and hepatitis A virus in the contaminant candidate list 4 as common drinking water microbial contaminants. The World Health Organization guidelines (2011) for drinking water quality classify astroviruses, hepatitis E virus, sapovirus, and rotavirus as important pathogens with some evidence for high health risks. There are conclusive evidences that viruses (e.g. rotavirus, norovirus, enterovirus) can be disseminated through aquatic environments (IAWPRC Study Group on Water Virology 1983; Riera-Montes et al. 2011; Scarcella et al. 2009), though little is known about the fate of ongoing pandemic of COVID-19 in aquatic phase. Thus, to prevent the outbreak and epidemic of viruses, it is very important to ensure the effective inactivation of viruses during disinfection, a final barrier in the processes of drinking water or wastewater treatment.

At present, there are many studies on the virucidal activity of $\mathrm{ClO}_{2}$ toward viruses, including nonenveloped viruses (e.g. 
bacteriophage, enterovirus, adenovirus, calicivirus, rotavirus and parvovirus) and enveloped viruses (e.g. influenza virus, measles virus, herpesvirus and distemper virus). Enveloped viruses differ structurally from nonenveloped viruses due to the presence of a lipid bilayer membrane outside the viral protein capsid, which contains proteins or glycoproteins. The different functional groups on the outer surface of enveloped viruses compared to nonenveloped viruses likely impact their survival and partitioning behavior in aqueous environments (Arbely et al. 2006; Gundy et al. 2009; Shigematsu et al. 2014). Many factors have been found to exert great impacts on virus inactivation rates such as $\mathrm{ClO}_{2}$ dosage, $\mathrm{pH}$, and temperature (Berman and Hoff 1984; Chen and Vaughn 1990; Hornstra et al. 2011; Thurston-Enriquez et al. 2005). The mechanisms of inactivation of virus by $\mathrm{ClO}_{2}$ include the disruption of the virus protein or the damage of genome (Jin et al. 2013,2012; Li et al. 2004; Sigstam et al. 2013; Wigginton et al. 2012). Understanding the virus inactivation kinetics upon $\mathrm{ClO}_{2}$ disinfection is a pressing need in environmental engineering for ensuring sufficient disinfectant doses. By elucidating inactivation efficiencies and mechanisms of viruses, we can better control waterborne viruses in water and wastewater treatment.

As such, the purpose of this review is to provide an overview of the kinetics and mechanisms of inactivation of viruses by $\mathrm{ClO}_{2}$ disinfection, and identify the research gap and future research directions.

\section{Inactivation Efficiencies of Diverse Viruses}

The inactivation efficiencies of different kinds of viruses are shown in Table 1. Generally, the inactivation efficiencies of bacteriophage and rotavirus are very high and $4 \log$ removal can be achieved within $0.06-1.45 \mathrm{mg} \mathrm{L}^{-1} \mathrm{~min}$ in disinfectant demand-free water under different $\mathrm{pH}$ and temperature (Berman and Hoff 1984; Hauchman et al. 1986; Sanekata et al. 2010). Canine parvovirus is relatively difficult to be inactivated and no obvious inactivation was observed within 2 min at a $\mathrm{ClO}_{2}$ dosage of $1.0 \mathrm{mg} \mathrm{L}^{-1}$ (Sanekata et al. 2010). For the same kind of virus, cell-associated simian rotavirus SA11 is more resistant to $\mathrm{ClO}_{2}$ than freely suspended virions (Berman and Hoff 1984). Interestingly, for closely related viruses, they can exhibit very different susceptibilities to $\mathrm{ClO}_{2}$. For example, in Sigstam's study (2013), although the genome sequences and the amino acid sequences in capsid protein of bacteriophage GA are $74 \%$ and $62 \%$ identical to that of MS2, respectively, the inactivation rate constant of GA is 2.84 times higher than that of MS2 during $\mathrm{ClO}_{2}$ disinfection. Sanekata et al. (2010) suggested that the inactivation of human adenovirus by $\mathrm{ClO}_{2}$ was rapider than canine adenovirus. Moreover, to achieve $99 \%$ inactivation, the required disinfection time for coxsackievirus B5 is half of that for coxsackievirus A9 (Scarpino 1979; Zoni et al. 2007). It suggested that even minor differences in composition of virus may result in substantial differences in inactivation kinetics. Future studies should pay more attention to molecular-level reactions of $\mathrm{ClO}_{2}$ on the different virus components so as to understand how the genome and amino acid sequences and their structures affect the reaction kinetics with $\mathrm{ClO}_{2}$ and how the alteration connects with the loss of infectivity.

The susceptibility of enveloped viruses to $\mathrm{ClO}_{2}$ is different from that of nonenveloped viruses. Nonenveloped human viruses such as human rotaviruses, adenoviruses and enteroviruses have been widely studied (Jin et al. 2013; ThurstonEnriquez et al. 2005; Xue et al. 2013). A number of highprofile outbreaks such as Ebola virus, measles, Zika virus, avian influenzas, SARS, MERS, and the ongoing COVID19 pandemic are caused by enveloped viruses (Aquino de Carvalho et al. 2017; Chen and Guo 2016; Das et al. 2020). Sanekata et al. (2010) suggested that the enveloped viruses (influenza virus, measles virus, human herpesvirus, canine distemper virus) experienced higher levels of inactivation than the nonenveloped viruses (human adenovirus, canine adenovirus, canine parvovirus, feline calicivirus) when being exposed to $1.0 \mathrm{mg} \mathrm{L}^{-1} \mathrm{ClO}_{2}$. Other researchers also suggested that enveloped viruses were much easier to be inactivated by free chlorine than nonenveloped ones (Gallandat and Lantagne 2017; Rice et al. 2007; Ye et al. 2018). The explanation could be that the $\mathrm{ClO}_{2}$ can react with proteins on the enveloped membrane, such as the spike glycoprotein, the damage of which results in the failure of attachment to the host cell and thus the unsuccessful cell invasion and infection (Casais et al. 2003; Li et al. 2003; Yang et al. 2004). When the data of various viruses is put together (Fig. 1), it can be seen that viruses that are difficult to be inactivated by $\mathrm{ClO}_{2}$ are non-enveloped ones. Additionally, unlike UV disinfection, there is no obvious correlation between inactivation rates and genome types of viruses (e.g. single-stranded DNA, double-stranded DNA, single-stranded RNA and double-stranded RNA) during $\mathrm{ClO}_{2}$ disinfection. It may be because virus inactivation mechanisms by $\mathrm{ClO}_{2}$ differ between different viruses, which may be caused by genome damage or protein disruption.

In order to give a whole picture of the removal of diverse viruses in water, Fig. 1 shows the relationship between the log removal of viruses and $\mathrm{Ct}$ values. It should be noted that most viruses can be effectively removed within $4 \mathrm{mg} \mathrm{L}^{-1} \mathrm{~min}$, however, some of enterovirus, calicivirus and adenovirus are difficult to be inactivated. According to the USEPA National Primary Drinking Water Standards (2003), public utilities must ensure a 4-log inactivation of viruses from source water. To meet this regulatory guideline, the $\mathrm{Ct}$ value must generally be more than $10 \mathrm{mg} \mathrm{L}^{-1} \cdot \mathrm{min}$. The threshold for chlorite in drinking water is set as $0.7 \mathrm{mg} \mathrm{L}^{-1}$ and $1 \mathrm{mg} \mathrm{L}^{-1}$ in China and USA, respectively (Ministry of 
Table 1 Inactivation of viruses by chlorine dioxide $\left(\mathrm{ClO}_{2}\right)$

\begin{tabular}{|c|c|c|c|c|c|}
\hline Virus & $\begin{array}{l}\text { Ct value } \\
\left(\mathrm{mg} \mathrm{min}^{-1}\right) / \mathrm{t} \\
(\min )^{\mathrm{a}}\end{array}$ & Inactivation & Experimental condition & Viral information & References \\
\hline \multicolumn{6}{|l|}{ Bacteriophage } \\
\hline Bacteriophage f2 & $2 \min$ & $>4 \log$ & $\begin{array}{l}0.6 \mathrm{mg} \mathrm{L}^{-1} \mathrm{ClO}_{2}, \mathrm{pH} 7.2 \text {, } \\
5^{\circ} \mathrm{C}\end{array}$ & \multirow[t]{5}{*}{$\begin{array}{l}\text { Nonenveloped virus with } \\
\text { single-stranded RNA }\end{array}$} & (Hauchman et al. 1986) \\
\hline Bacteriophage f2 & $2 \min$ & $<2 \log$ & $\begin{array}{l}0.4 \mathrm{mg} \mathrm{L}^{-1} \mathrm{ClO}_{2}, \mathrm{pH} 7.0 \\
5^{\circ} \mathrm{C}\end{array}$ & & (Taylor and Butler 1982) \\
\hline Bacteriophage MS2 & $0.42 \mathrm{mg} \min \mathrm{L}^{-1}$ & $4 \log$ & $\mathrm{pH} 7.2,5^{\circ} \mathrm{C}$ & & (Lim et al. 2010) \\
\hline Bacteriophage MS2 & $4 \mathrm{mg} \min \mathrm{L}^{-1}$ & $5 \log$ & $\mathrm{pH} 7.2,0^{\circ} \mathrm{C}$ & & (Hornstra et al. 2011) \\
\hline Bacteriophage MS2 & $0.48 \mathrm{mg} \min \mathrm{L}^{-1}$ & $4 \log$ & $\mathrm{pH} 7.2,20^{\circ} \mathrm{C}$ & & (Jin et al. 2013) \\
\hline \multicolumn{6}{|l|}{ Enterovirus } \\
\hline Enterovirus 71 & $3.93 \mathrm{mg} \min \mathrm{L}^{-1}$ & $4 \log$ & $\mathrm{pH} 7.2,20^{\circ} \mathrm{C}$ & \multirow{8}{*}{$\begin{array}{l}\text { Nonenveloped virus with } \\
\text { single-stranded RNA }\end{array}$} & (Jin et al. 2013) \\
\hline Echovirus 11 & $1.0 \mathrm{mg} \min \mathrm{L}^{-1}$ & $6 \log$ & $\mathrm{pH} 7.4$ & & (Zhong et al. 2017) \\
\hline Coxsackievirus A9 & $1.16 \mathrm{~min}$ & $2 \log$ & $\begin{array}{l}0.4 \mathrm{mg} \mathrm{L}^{-1} \mathrm{ClO}_{2}, \mathrm{pH} 7.0 \\
15^{\circ} \mathrm{C}\end{array}$ & & (Scarpino 1979) \\
\hline Coxsackievirus B5 & $2.41 \mathrm{~min}$ & $4 \log$ & $\begin{array}{l}0.4 \mathrm{mg} \mathrm{L}^{-1} \mathrm{ClO}_{2}, \mathrm{pH} \text { 7.0, } \\
20^{\circ} \mathrm{C}\end{array}$ & & (Zoni et al. 2007) \\
\hline Poliovirus & $10 \mathrm{~min}$ & $2 \log$ & $\begin{array}{l}1.0 \mathrm{mg} \mathrm{L}^{-1} \mathrm{ClO}_{2}, \mathrm{pH} \text { 6.0, } \\
25^{\circ} \mathrm{C}\end{array}$ & & (Alvarez and Brien 1982) \\
\hline Poliovirus & $10 \mathrm{~min}$ & $<2 \log$ & $\begin{array}{l}0.4 \mathrm{mg} \mathrm{L}^{-1} \mathrm{ClO}_{2}, \mathrm{pH} 7.0 \\
5^{\circ} \mathrm{C}\end{array}$ & & (Taylor and Butler 1982) \\
\hline Poliovirus & $2.5 \mathrm{~min}$ & $4 \log$ & $\begin{array}{l}1.0 \mathrm{mg} \mathrm{L}^{-1} \mathrm{ClO}_{2}, \mathrm{pH} 7.0 \text {, } \\
20^{\circ} \mathrm{C}\end{array}$ & & (Tachikawa et al. 1993) \\
\hline Hepatitis A virus & $19.58 \mathrm{~min}$ & $4 \log$ & $\begin{array}{l}0.4 \mathrm{mg} \mathrm{L}^{-1} \mathrm{ClO}_{2}, \mathrm{pH} 7.0 \\
20^{\circ} \mathrm{C}\end{array}$ & & (Zoni et al. 2007) \\
\hline \multicolumn{6}{|l|}{ Rotavirus } \\
\hline Human rotavirus & $1.21 \mathrm{mg} \mathrm{min} \mathrm{L}^{-1}$ & $4 \log$ & $\mathrm{pH} 7.2,20^{\circ} \mathrm{C}$ & \multirow{5}{*}{$\begin{array}{l}\text { Nonenveloped virus with } \\
\text { double-stranded RNA }\end{array}$} & (Xue et al. 2013) \\
\hline Human rotavirus type 2 & $1 \mathrm{~min}$ & $4 \log$ & $\begin{array}{l}0.2 \mathrm{mg} \mathrm{L}-1 \\
5^{\circ} \mathrm{ClO}\end{array}$ & & (Chen and Vaughn 1990) \\
\hline Simian rotavirus SA11 & $0.37 \mathrm{~min}$ & $4 \log$ & $\begin{array}{l}0.17 \mathrm{mg} \mathrm{L}^{-1} \mathrm{ClO}_{2}, \mathrm{pH} 7, \\
5^{\circ} \mathrm{C}\end{array}$ & & (Chen and Vaughn 1990) \\
\hline Simian rotavirus SA11 & $0.28 \mathrm{mg} \min \mathrm{L}^{-1}$ & $2 \log$ & $\mathrm{pH} 6,5^{\circ} \mathrm{C}$ & & (Berman and Hoff 1984) \\
\hline $\begin{array}{l}\text { Cell-associated simian } \\
\text { rotavirus SA11 }\end{array}$ & $1.45 \mathrm{mg} \mathrm{min} \mathrm{L}^{-1}$ & $4 \log$ & $\mathrm{pH} 6,5^{\circ} \mathrm{C}$ & & (Berman and Hoff 1984) \\
\hline \multicolumn{6}{|l|}{ Adenovirus } \\
\hline Adenovirus type 40 & $0.12 \mathrm{mg} \min \mathrm{L}^{-1}$ & $4 \log$ & $\mathrm{pH} 8,15^{\circ} \mathrm{C}$ & \multirow[t]{4}{*}{$\begin{array}{l}\text { Nonenveloped virus with } \\
\text { double-stranded DNA }\end{array}$} & $\begin{array}{l}\text { (Thurston-Enriquez et al. } \\
\text { 2005) }\end{array}$ \\
\hline Human adenovirus & $2 \min$ & $1.5 \log$ & $1.0 \mathrm{mg} \mathrm{L}^{-1} \mathrm{ClO}_{2}$ & & (Sanekata et al. 2010) \\
\hline Canine adenovirus & $2 \min$ & $0.5 \log$ & $1.0 \mathrm{mg} \mathrm{L}^{-1} \mathrm{ClO}_{2}$ & & (Sanekata et al. 2010) \\
\hline Parvovirus & & & & & \\
\hline Canine parvovirus & $2 \min$ & $0 \log$ & $1.0 \mathrm{mg} \mathrm{L}^{-1} \mathrm{ClO}_{2}$ & $\begin{array}{l}\text { Nonenveloped virus with } \\
\text { single-stranded DNA }\end{array}$ & (Sanekata et al. 2010) \\
\hline \multicolumn{6}{|l|}{ Calicivirus } \\
\hline Feline calicivirus & $0.18 \mathrm{mg} \min \mathrm{L}^{-1}$ & $4 \log$ & $\mathrm{pH} 8,15^{\circ} \mathrm{C}$ & \multirow[t]{4}{*}{$\begin{array}{l}\text { Nonenveloped virus with } \\
\text { single-stranded RNA }\end{array}$} & $\begin{array}{l}\text { (Thurston-Enriquez et al. } \\
\text { 2005) }\end{array}$ \\
\hline Feline calicivirus & $9.59 \mathrm{~min}$ & $4 \log$ & $\begin{array}{l}0.4 \mathrm{mg} \mathrm{L}^{-1} \mathrm{ClO}_{2}, \mathrm{pH} \text { 7.0, } \\
20^{\circ} \mathrm{C}\end{array}$ & & (Zoni et al. 2007) \\
\hline Feline calicivirus & $2 \min$ & $0.25 \log$ & $1.0 \mathrm{mg} \mathrm{L}^{-1} \mathrm{ClO}_{2}$ & & (Sanekata et al. 2010) \\
\hline Murine norovirus & $0.25 \mathrm{mg} \min \mathrm{L}^{-1}$ & $4 \log$ & $\mathrm{pH} 7.2,5^{\circ} \mathrm{C}$ & & (Lim et al. 2010) \\
\hline \multicolumn{6}{|l|}{ Influenza virus } \\
\hline Influenza A virus $\mathrm{H} 1 \mathrm{~N} 1$ & $5 \min$ & $>4.5 \log$ & $0.5 \mathrm{mg} \mathrm{L}^{-1} \mathrm{ClO}_{2}, 25^{\circ} \mathrm{C}$ & \multirow{3}{*}{$\begin{array}{l}\text { Enveloped virus with } \\
\text { single-stranded RNA }\end{array}$} & (Lénès et al. 2010) \\
\hline Influenza A virus $\mathrm{H} 5 \mathrm{~N} 1$ & $5 \mathrm{~min}$ & $>4 \log$ & $0.3 \mathrm{mg} \mathrm{L}^{-1} \mathrm{ClO}_{2}, 25^{\circ} \mathrm{C}$ & & (Lénès et al. 2010) \\
\hline Influenza virus & $2 \mathrm{~min}$ & $5 \log$ & $1.0 \mathrm{mg} \mathrm{L}^{-1} \mathrm{ClO}_{2}$ & & (Sanekata et al. 2010) \\
\hline
\end{tabular}


Table 1 (continued)

\begin{tabular}{|c|c|c|c|c|c|}
\hline Virus & $\begin{array}{l}\text { Ct value } \\
\left(\mathrm{mg} \min \mathrm{L}^{-1}\right) / \mathrm{t} \\
(\mathrm{min})^{\mathrm{a}}\end{array}$ & Inactivation & Experimental condition & Viral information & References \\
\hline \multicolumn{6}{|l|}{ Other enveloped viruses } \\
\hline Measles virus & $2 \min$ & $1.75 \log$ & $1.0 \mathrm{mg} \mathrm{L}^{-1} \mathrm{ClO}_{2}$ & $\begin{array}{l}\text { Enveloped virus with } \\
\text { single-stranded RNA }\end{array}$ & (Sanekata et al. 2010) \\
\hline Human herpesvirus & $2 \mathrm{~min}$ & $2.5 \log$ & $1.0 \mathrm{mg} \mathrm{L}^{-1} \mathrm{ClO}_{2}$ & $\begin{array}{l}\text { Enveloped virus with } \\
\text { double-stranded DNA }\end{array}$ & (Sanekata et al. 2010) \\
\hline Canine distemper virus & $2 \mathrm{~min}$ & $3.75 \log$ & $1.0 \mathrm{mg} \mathrm{L}^{-1} \mathrm{ClO}_{2}$ & $\begin{array}{l}\text { Enveloped virus with } \\
\text { single-stranded RNA }\end{array}$ & (Sanekata et al. 2010) \\
\hline
\end{tabular}

${ }^{\mathrm{a}} \mathrm{Ct}$ values were used preferentially. For the papers without giving $\mathrm{Ct}$ values, time and initial $\mathrm{ClO}_{2}$ concentration were provided, respectively. The classification of viruses is carried out according to the standard issued by International Committee on Taxonomy of Viruses (http://www.ictvo nline.org/)

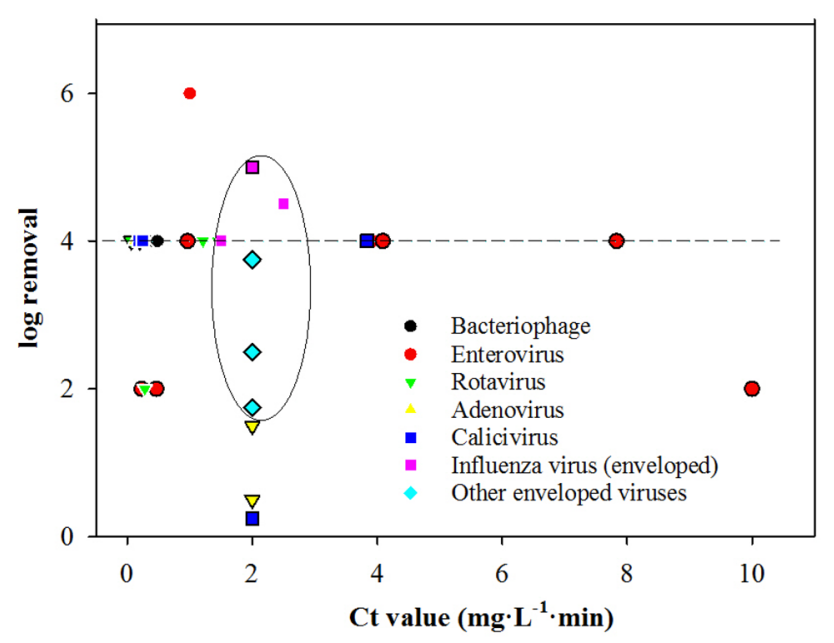

Fig. 1 The log removal of viruses during $\mathrm{ClO}_{2}$ disinfection. Note: the data of enveloped virus is circled; the line indicates the variations of $\mathrm{Ct}$ values to achieve the 4-log removal. The legend with a black edge indicates that $\mathrm{Ct}$ value is the product of initial concentration of $\mathrm{ClO}_{2}$ and contact time

Health 2006; USEPA 2006). In general, the applied $\mathrm{ClO}_{2}$ dosage in drinking water disinfection is less than $1.5 \mathrm{mg} \mathrm{L}^{-1}$ considering that $30-70 \%$ of $\mathrm{ClO}_{2}$ is converted into chlorite (Schmidt et al. 2000; Sorlini et al. 2014; Yang et al. 2013). As such, the contact time for $\mathrm{ClO}_{2}$ disinfection is generally in the range of tens of minutes.

\section{Effect of Experimental Conditions on Inactivation Kinetics}

Viruses inactivation by $\mathrm{ClO}_{2}$ experiences an initial phase of pseudo first-order decay followed by a phase of slower kinetics or a tailing effect (Fig. S1). The occurrence of tailing is common in virus disinfection by $\mathrm{ClO}_{2}$ including bacteriophage MS2 (Hornstra et al. 2011), enterovirus 71 (Jin et al. 2013), human and simian rotavirus (Berman and Hoff 1984; Chen and Vaughn 1990), murine norovirus (Lim et al. 2010), echovirus 11 (Zhong et al. 2017), enteric adenovirus and feline calicivirus (Thurston-Enriquez et al. 2005). It has been reported that heterogeneity of the virus population or virus attachment to other (virus) particles could be responsible for the tailing behavior (Gerba et al. 2003; Hornstra et al. 2011; Keswick et al. 1985; Thurston-Enriquez et al. 2003). However, Sigstam et al. (2014) suggested that the tailing behavior of MS2 was not caused by virus aggregation or by resistant subgroup, but due to the deposition of disinfection intermediates onto the virus capsid, protecting the viruses from further disinfection.

The initial fast inactivation phase of viruses exhibits a significant dose effect, that is, the inactivation rates increase with increasing $\mathrm{ClO}_{2}$ dosages, but the second phase shows less difference (Fig. S1a) (Jin et al. 2013). Higher dose of $\mathrm{ClO}_{2}$ has stronger disinfecting capacity (Katz et al. 1994), thus, it can inactivate viruses in a short time. However, when the contact time is longer enough, lower dose of $\mathrm{ClO}_{2}$ can also effectively penetrate surface structure of viruses and lead to their death (Lin et al. 2014). Therefore, longer contact time may weaken the influence of dosage on the inactivation of viruses and remedy the insufficient disinfectant.

The virus inactivation rates in $\mathrm{ClO}_{2}$ disinfection increase rapidly with increasing $\mathrm{pH}$. For example, enterovirus 71 exhibits a higher inactivation efficiency toward $\mathrm{ClO}_{2}$ at $\mathrm{pH}$ of 8.2 than $\mathrm{pH}$ of 5.6, as shown in Table 2 and Fig. S1b (Jin et al. 2013). Poliovirus is found to be inactivated 4.6 times faster at $\mathrm{pH}$ of 9.0 than that at $\mathrm{pH}$ of 7.0 , and 8.3 times faster than that at $\mathrm{pH}$ of 4.5 at $21{ }^{\circ} \mathrm{C}$ (Scarpino 1979). The inactivation of bacteriophage $\mathrm{f} 2$ increases by more than 5 $\log$ after treatment with $\mathrm{ClO}_{2}$ for 2 min when $\mathrm{pH}$ increases from 5.0 to 9.0 (Taylor and Butler 1982). Enhanced inactivation with increasing $\mathrm{pH}$ is also observed in adenovirus type 40 (Thurston-Enriquez et al. 2005), feline calicivirus 
Table $2 \mathrm{pH}$ effect on viruses inactivation by chlorine dioxide

\begin{tabular}{|c|c|c|c|c|c|}
\hline Virus & Experimental condition & Survival & 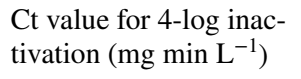 & $\begin{array}{l}\text { Time for 3-log inactiva- } \\
\text { tion }(s)\end{array}$ & References \\
\hline Poliovirus & $\begin{array}{l}0.4 \mathrm{mg} \mathrm{L}^{-1} \mathrm{ClO}_{2}, 5^{\circ} \mathrm{C}, \\
10 \mathrm{~min}\end{array}$ & $\begin{array}{l}25 \%(\mathrm{pH} \\
5)>8 \%(\mathrm{pH} \\
7)>0.08 \% \\
(\mathrm{pH} 9)\end{array}$ & Not available & Not available & (Taylor and Butler 1982) \\
\hline Coliphage f2 & $\begin{array}{l}0.4 \mathrm{mg} \mathrm{L}^{-1} \mathrm{ClO}_{2}, 5^{\circ} \mathrm{C} \\
\quad 2 \mathrm{~min}\end{array}$ & $\begin{array}{l}70 \%(\mathrm{pH} \\
5)>5.5 \% \\
(\mathrm{pH} \\
7)>0.0004 \% \\
(\mathrm{pH} 9)\end{array}$ & Not available & Not available & (Taylor and Butler 1982) \\
\hline Adenovirus type 40 & $5^{\circ} \mathrm{C}$ & Not available & $\begin{array}{l}1.28(\mathrm{pH} 6)>0.67 \\
\quad(\mathrm{pH} 8)\end{array}$ & Not available & $\begin{array}{l}\text { (Thurston-Enriquez et al. } \\
\text { 2005) }\end{array}$ \\
\hline Feline calicivirus & $5^{\circ} \mathrm{C}$ & Not available & $\begin{array}{l}20.85(\mathrm{pH} 6)>1.08 \\
\quad(\mathrm{pH} 8)\end{array}$ & Not available & $\begin{array}{l}\text { (Thurston-Enriquez et al. } \\
\text { 2005) }\end{array}$ \\
\hline Enterovirus 71 & $1.5 \mathrm{mg} \mathrm{L}^{-1} \mathrm{ClO}_{2}, 20^{\circ} \mathrm{C}$ & Not available & $\begin{array}{l}10.7(\mathrm{pH} 5.6)>6.62 \\
(\mathrm{pH} 7.2)>4.92(\mathrm{pH} \\
8.2)\end{array}$ & Not available & (Jin et al. 2013) \\
\hline Simian rotavirus SA11 & $0.2 \mathrm{mg} \mathrm{L}^{-1} \mathrm{ClO}_{2}, 4^{\circ} \mathrm{C}$ & Not available & Not available & $\begin{array}{c}160(\mathrm{pH} 6)>60(\mathrm{pH} \\
7)>6(\mathrm{pH} 8)\end{array}$ & (Chen and Vaughn 1990) \\
\hline Human rotaviruses & $0.2 \mathrm{mg} \mathrm{L}^{-1} \mathrm{ClO}_{2}, 4^{\circ} \mathrm{C}$ & Not available & Not available & $65(\mathrm{pH} 6)>6(\mathrm{pH} 8)$ & (Chen and Vaughn 1990) \\
\hline
\end{tabular}

(Thurston-Enriquez et al. 2005), human rotavirus (Chen and Vaughn 1990) and simian rotavirus SA11 (Berman and Hoff 1984; Chen and Vaughn 1990). Unlike dose effect, pH does not affect the initial inactivation phase so strongly, but seems to have an effect on the tailing phase. Noss and Olivieri (1985) hypothesized that the results may attribute to the change of the surface structure of the virion and the concentration of hydroxyl ion in the solution. In addition, individual virions in suspension may be induced to aggregate when the $\mathrm{pH}$ decreases due to the elimination of repulsive electrostatic force (isoelectric points of viruses are approximately 4.0). Viral aggregates have been reported to increase the survival of viruses in the environment and resistance to disinfectants (Clark 1968; Hoff and Akin 1986; Mattle et al. 2011). Therefore, lower $\mathrm{pH}$ is unfavorable for virus inactivation during $\mathrm{ClO}_{2}$ disinfection.

The inactivation rates of viruses by $\mathrm{ClO}_{2}$ are temperature-dependent and the inactivation efficiency is enhanced as temperature increases from $5{ }^{\circ} \mathrm{C}$ to $25^{\circ} \mathrm{C}$ (Fig. S1c) (Jin et al. 2013). It is also reported that infectivity of enveloped bacteriophage Phi6 in droplets decreases by two orders of magnitude when the temperature increases from $19{ }^{\circ} \mathrm{C}$ to $25^{\circ} \mathrm{C}$ (Prussin et al. 2018). It can be rationalized that the activation energy of $\mathrm{ClO}_{2}$ for killing viruses become lower at a higher temperature ( $\mathrm{Ji}$ et al. 2008). However, in the study of Grunert et al. (2018), the inactivation rate constants of bacteriophage PRD1 slightly decreased when temperature increases from $15^{\circ} \mathrm{C}$ to $25^{\circ} \mathrm{C}$, due to the decomposition of $\mathrm{ClO}_{2}$ at higher temperatures.

The inactivation efficiencies of viruses are also affected by water matrix. Studies have shown that better inactivation efficiencies of bacteriophage $\mathrm{f} 2$ and coxsackievirus B5 were observed in phosphate buffer solution than in hospital wastewater or municipal wastewater (Harakeh 1987; Taylor and Butler 1982; Wang et al. 2005; Zoni et al. 2007), primarily due to the competitive consumption of $\mathrm{ClO}_{2}$ by dissolved organic matter in wastewater or protective effect of particulates adsorbed on the viruses (Lin et al. 2014; Scarpino 1979; Fujioka et al. 1986). On the other hand, opposite trends are also observed. When the dissolved organic matter concentrations increased from 0.2 to $2.0 \mathrm{mgC} \mathrm{L}^{-1}$, bacteriophage PRD1 showed enhanced inactivation percentages and MS2 showed little difference in inativation precentages upon $\mathrm{ClO}_{2}$ disinfection (Grunert et al. 2018). By-products, not chlorite and chlorate, were proposed to be responsible for the enhanced disinfection (Barbeau et al. 2005). Ammonia in water hardly affected the inactivation efficiency of bacteriophage f2 (Taylor and Butler 1982).

\section{Inactivation Mechanisms}

For an infectious virus, it should be able to bind to its host cell, inject its genome inside the host cell, and replicate and translate once its genome gets into the host cell. All of these functions must be intact for the virus to be infective. In other words, to inactivate the virus, at least one of these functions must be destroyed.

Due to the different composition and three-dimensional structure of proteins and nucleic acids, the virucidal mechanism of $\mathrm{ClO}_{2}$ appears to be different for different types of viruses (Fig. 2). In bacteriophage such as MS2, fr and GA, 
Fig. 2 Inactivation mechanisms of viruses by $\mathrm{ClO}_{2}$

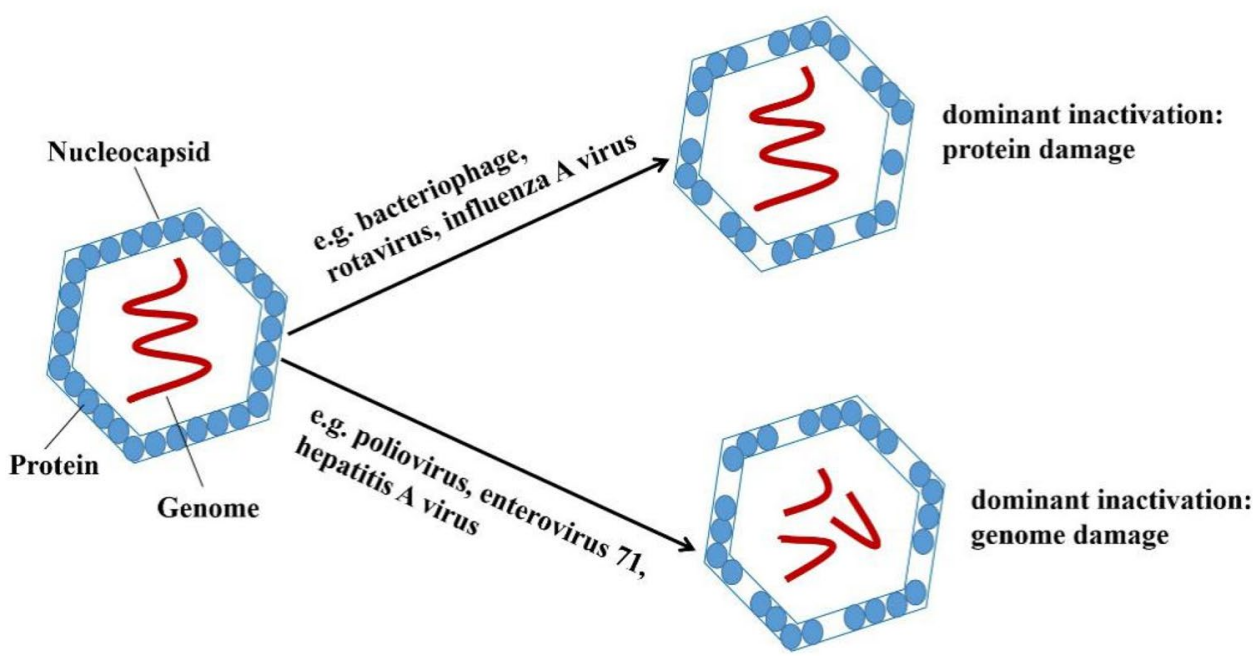

the mode of action of $\mathrm{ClO}_{2}$ mainly involves the degradation of the viral capsid proteins, which are largely responsible for interactions with the host cell and injection mechanisms (Hauchman et al. 1986; Noss et al. 1986; Sigstam et al. 2013; Wigginton et al. 2012). Therefore, the attachment of virus to host cells is inhibited, resulting in the inactivation of viruses. The denaturation of virus proteins is also reported to be the dominant inactivation mechanism upon $\mathrm{ClO}_{2}$ disinfection of human rotavirus and there is no genome damage (Xue et al. 2013). Zhu et al. (2019) suggested that destruction of membrane glycoprotein GP2a and GP4 by $\mathrm{ClO}_{2}$ blocked the interaction between porcine reproductive and respiratory syndrome virus (PRRSV) and cell receptors, leading to the termination of life cycle of this virus.

Considering the high reactivity of cysteine $\left(1.0 \times 10^{7} \mathrm{M}^{-1} \mathrm{~s}^{-1}\right.$ at $\mathrm{pH}$ 7.0) (Ison et al. 2006), tyrosine $\left(1.4 \times 10^{5} \mathrm{M}^{-1} \mathrm{~s}^{-1}\right.$ at $\mathrm{pH}$ 7.0) (Napolitano et al. 2005) and tryptophan $\left(3.4 \times 10^{4} \mathrm{M}^{-1} \mathrm{~s}^{-1}\right.$ at $\mathrm{pH}$ 7.0) (Stewart et al. 2008) with $\mathrm{ClO}_{2}$ and their prevalence in diverse proteins, cysteine, tyrosine and tryptophan residues have been reported to be critical targets in the reaction between $\mathrm{ClO}_{2}$ and proteins, causing fragmentation and denaturation of proteins (Ogata 2007), though the reactivity of amino acid residue in protein are lower than that of free tryptophan (Ge et al. 2020). For example, $\mathrm{ClO}_{2}$ inactivation of influenza $\mathrm{A}$ virus is due to the oxidation of a tryptophan residue (W153) in the viral protein hemagglutinin, destroying its ability to bind with host cells (Ogata 2012). However, in enteroviruses such as poliovirus, enterovirus 71 and hepatitis A virus, $\mathrm{ClO}_{2}$ has been proposed to act on the viral genome. Specifically, the inactivation by $\mathrm{ClO}_{2}$ is caused by damage in the $5^{\prime}$ noncoding region within the genome, which is necessary for the formation of new virus particles within the host cell (Jin et al. 2013, 2012; $\mathrm{Li}$ et al. 2004). Moreover, it has been reported that although protein damage plays an important role in inactivation of poliovirus, inactivation is ultimately attributed to viral RNA damage (Alvarez and O'Brien 1982; Simonet and Gantzer 2006). Disinfection resistance of viruses is closely related to these two kinds of inactivation mechanisms by $\mathrm{ClO}_{2}$ and the details are provided in Text S1.

\section{Future Perspectives}

This review summarized the inactivation efficiencies, kinetics and mechanisms of diverse viruses toward $\mathrm{ClO}_{2}$ based on the published literature. Further studies should focus on the causes of the tailing behavior, the effect of real water matrices on virus inactivation, and specific chemical modifications in the genome and capsid as well as their effects on viral structure and function (details in Text S2).

Supplementary Information The online version contains supplementary material available at https://doi.org/10.1007/s00128-021-03137-3.

Acknowledgements This work was supported by the National Key Research and Development Program of China (No. 2017YFE0133200) and Guangdong Provincial Science and Technology Planning Project (No. 2019A050503006).

\section{References}

Alvarez ME, Brien RT (1982) Mechanisms of inactivation of poliovirus by chlorine dioxide and iodine. Appl Environ Microbiol 44:1064-1071

Aquino de Carvalho N, Stachler EN, Cimabue N, Bibby K (2017) Evaluation of Phi6 persistence and suitability as an enveloped virus surrogate. Environ Sci Technol 51:8692-8700

Arbely E, Granot Z, Kass I, Orly J, Arkin IT (2006) A trimerizing GxxxG motif is uniquely inserted in the severe acute respiratory syndrome (SARS) coronavirus spike protein transmembrane domain. Biochemistry 45:11349-11356 
Aronino R, Dlugy C, Arkhangelsky E, Shandalov S, Oron G, Brenner A, Gitis V (2009) Removal of viruses from surface water and secondary effluents by sand filtration. Water Res 43:87-96

AWWA Water Quality Division (2000) Committee report: disinfection at large and medium-size systems. J Am Water Work Assoc 92:32-43

Barbeau B, Huffman D, Mysore C, Desjardins R, Clément B, Prévost M (2005) Examination of discrete and counfounding effects of water quality parameters during the inactivation of MS2 phages and Bacillus subtilis spores with chlorine dioxide. J Environ Eng Sci 4:139-151

Berman D, Hoff JC (1984) Inactivation of simian rotavirus SA11 by chlorine, chlorine dioxide, and monochloramine. Appl Environ Microbiol 48:317-323

Casais R, Dove B, Cavanagh D, Britton P (2003) Recombinant avian infectious bronchitis virus expressing a heterologous spike gene demonstrates that the spike protein is a determinant of cell tropism. J Virol 77:9084-9089

Chang CY, Hsieh YH, Hsu SS, Hu PY, Wang KH (2000) The formation of disinfection by-products in water treated with chlorine dioxide. J Hazard Mater 79:89-102

Chauret CP, Radziminski CZ, Lepuil M, Creason R, Andrews RC (2001) Chlorine dioxide inactivation of Cryptosporidium parvum oocysts and bacterial spore indicators. Appl Environ Microbiol 67:2993-3001

Chen Q, Guo Y (2016) Influenza viral hemagglutinin peptide inhibits influenza viral entry by shielding the host receptor. ACS Infect Dis 2:187-193

Chen YS, Vaughn JM (1990) Inactivation of human and simian rotaviruses by chlorine dioxide. Appl Environ Microbiol 56:1363-1366

Choe JK, Richards DH, Wilson CJ, Mitch WA (2015) Degradation of amino acids and structure in model proteins and bacteriophage MS2 by chlorine, bromine, and ozone. Environ Sci Technol 49:13331-13339

Clark RM (1968) A mathematical model of the kinetics of viral devitalization. Math Biosci 2:413-423

Das G, Mukherjee N, Ghosh S (2020) Neurological insights of COVID19 pandemic. ACS Chem Neurosci 11:1206-1209

US EPA (2003) National primary drinking water standards. Office of Water, US Environmental Protection Agency, , Washington

Epa US (2006) National primary drinking water regulations: stage 2 disinfectants and disinfection byproducts rule. Fed Regist 71:388-493

US EPA (2018) Contaminant candidate list (CCL) and regulatory determination. https//www.epa.gov/ccl/microbial contaminantsccl-4. Accessed 30 Mar 2018

Fujioka RS, Dow MA, Yoneyama BS (1986) Comparative disinfection of indicator bacteria and poliovirus by chlorine dioxide. Water Sci Technol 18:125-132

Fulton G, Budd G (1992) Disinfection alternatives for safe drinking water. Environ Sci Technol 27:2295-2297

Gallandat K, Lantagne D (2017) Selection of a biosafety level 1 (BSL1) surrogate to evaluate surface disinfection efficacy in Ebola outbreaks: comparison of four bacteriophages. PLoS ONE 12:1-10

Gan W, Ge Y, Zhong Y, Yang X (2020) The reactions of chlorine dioxide with inorganic and organic compounds in water treatment: kinetics and mechanisms. Environ Sci Water Res Technol 6:2287-2312

Ge Y, Lei Y, Lei X, Gan W, Shu L, Yang X (2020) Exploration of reaction rates of chlorine dioxide with tryptophan residue in oligopeptides and proteins. J Environ Sci (China) 93:129-136

Gerba CP, Nwachuku N, Riley KR (2003) Disinfection resistance of waterborne pathogens on the United States Environmental Protection Agency's contaminant candidate list (CCL). J Water Supply Res T 52:81-94
Grunert A, Frohnert A, Selinka HC, Szewzyk R (2018) A new approach to testing the efficacy of drinking water disinfectants. Int J Hyg Environ Health 221:1124-1132

Gundy PM, Gerba CP, Pepper IL (2009) Survival of coronaviruses in water and wastewater. Food Environ Virol 1:10-14

Harakeh S (1987) The behavior of viruses on disinfection by chlorine dioxide and other disinfectants in effluent. FEMS Microbiol Lett 44:335-341

Hauchman FS, Noss CI, Olivieri VP (1986) Chlorine dioxide reactivity with nucleic acids. Water Res 20:357-361

Hoff J, Akin E (1986) Microbial resistance to disinfectants: mechanisms and significance. Environ Health Persp 69:7-13

Hornstra LM, Smeets PWMH, Medema GJ (2011) Inactivation of bacteriophage MS2 upon exposure to very low concentrations of chlorine dioxide. Water Res 45:1847-1855

Huang J, Ren N, Wang L, Ma F, Juli, (1996) Disinfection effect of chlorine dioxide on bacteria in water. Water Res 31:607-613

Huang J, Wang L, Ren N, Liu X, Sun R, Yang G (1997) Disinfection effect of chlorine dioxide on viruses, algae and animal planktons in water. Water Res 31:455-460

IAWPRC Study Group on Water Virology (1983) The health significance of viruses in water. Water Res 17:121-132

Ison A, Odeh IN, Margerum DW (2006) Kinetics and mechanisms of chlorine dioxide and chlorite oxidations of cysteine and glutathione. Inorg Chem 45:8768-8775

Ji Y, Huang J, Fu J, Wu M, Cui C (2008) Degradation of microcystin-RR in water by chlorine dioxide. J China Univ Min Technol 18:623-628

Jin $\mathrm{M}$ et al (2012) The $40-80 \mathrm{nt}$ region in the $5^{\prime}$-NCR of genome is a critical target for inactivating poliovirus by chlorine dioxide. J Med Virol 84:526-535

Jin $\mathrm{M}$ et al (2013) Chlorine dioxide inactivation of enterovirus 71 in water and its impact on genomic targets. Environ Sci Technol 47:4590-4597

Katz A, Narkis N, Orshansky F, Friedland E, Kott Y (1994) Disinfection of effluent by combinations of equal doses of chlorine dioxide and chlorine added simultaneously over varying contact times. Water Res 28:2133-2138

Keswick BH et al (1985) Inactivation of Norwalk virus in drinking water by chlorine. Appl Environ Microbiol 50:261-264

Korich DG, Mead JR, Madore MS, Sinclair NA, Sterling CR (1990) Effects of ozone, chlorine dioxide, chlorine, and monochloramine on Cryptosporidium parvum oocyst viability. Appl Environ Microbiol 56:1423-1428

Korn C, Andrews RC, Escobar MD (2002) Development of chlorine dioxide-related by-product models for drinking water treatment. Water Res 36:330-342

Lénès D, Deboosere N, Ménard-Szczebara F, Jossent J, Alexandre V, Machinal C, Vialette M (2010) Assessment of the removal and inactivation of influenza viruses $\mathrm{H} 5 \mathrm{~N} 1$ and $\mathrm{H} 1 \mathrm{~N} 1$ by drinking water treatment. Water Res 44:2473-2486

Li W et al (2003) Angiotensin-converting enzyme 2 is a functional receptor for the SARS coronavirus. Nature 426:450-454

Li JW, Xin ZT, Wang XW, Zheng JL, Chao FH (2004) Mechanisms of inactivation of hepatitis A virus in water by chlorine dioxide. Water Res 38:1514-1519

Lim MY, Kim JM, Ko G (2010) Disinfection kinetics of murine norovirus using chlorine and chlorine dioxide. Water Res 44:3243-3251

Lin T, Chen W, Cai B (2014) The use of chlorine dioxide for the inactivation of copepod zooplankton in drinking water treatment. Environ Technol 35:2846-2851

Mamane H, Shemer H, Linden KG (2007) Inactivation of E. coli, B. subtilis spores, and MS2, T4, and T7 phage using $\mathrm{UV} / \mathrm{H}_{2} \mathrm{O}_{2}$ advanced oxidation. J Hazard Mater 146:479-486 
Mattle MJ, Crouzy B, BrenneckeWigginton MKR, Perona P, Kohn T (2011) Impact of virus aggregation on inactivation by peracetic acid and implications for other disinfectants. Environ Sci Technol 45:7710-7717

Ministry of Health (2006) Standards for drinking water quality (GB5749-2006). Ministry of Health of the People's Republic of China, Beijing

Napolitano MJ, Green BJ, Nicoson JS, Margerum DW (2005) Chlorine dioxide oxidations of tyrosine, $\mathrm{N}$-acetyltyrosine, and dopa. Chem Res Toxicol 18:501-508

Noss CI, Olivieri VP (1985) Disinfecting capabilities of oxychlorine compounds. Appl Environ Microbiol 50:1162-1164

Noss CI, Hauchman FS, Olivieri VP (1986) Chlorine dioxide reactivity with proteins. Water Res 20:351-356

Ogata N (2007) Denaturation of protein by chlorine dioxide: oxidative modification of tryptophan and tyrosine residues. Biochemistry 46:4898-4911

Ogata N (2012) Inactivation of influenza virus haemagglutinin by chlorine dioxide: oxidation of the conserved tryptophan 153 residue in the receptor-binding site. J Gen Virol 93:2558-2563

Prussin AJ, Schwake DO, Lin K, Gallagher DL, Buttling L, Marr LC (2018) Survival of the enveloped virus Phi6 in droplets as a function of relative humidity, absolute humidity, and temperature. Appl Environ Microbiol 84:e055118

Rice E, Adcock N, Sivaganesan M, Brown J, Stallknecht D (2007) Chlorine inactivation of highly pathogenic avian influenza virus (H5N1). Emerg Infect Dis 13:1568-1570

Riera-Montes M, Brus Sjölander K, Allestam G, Hallin E, Hedlund KO, Löfdahl M (2011) Waterborne norovirus outbreak in a municipal drinking-water supply in Sweden. Epidemiol Infect 139:1928-1935

Sanekata T et al (2010) Evaluation of the antiviral activity of chlorine dioxide and sodium hypochlorite against feline calicivirus, human influenza virus, measles virus, canine distemper virus, human herpesvirus, human adenovirus, canine adenovirus and canine parvovirus. Biocontrol Sci 15:45-49

Scarcella C et al (2009) An outbreak of viral gastroenteritis linked to municipal water supply, Lombardy, Italy, June 2009. Eurosurveillance 14:19274-19277

Scarpino PV (1979) Effect of particulates on disinfection of enteroviruses in water by chlorine dioxide. Office of Research and Development, US Environmental Protection Agency, Washington, DC

Schmidt W, Böhme U, Sacher F, Brauch HJ (2000) Minimization of disinfection by-products formation in water purification process using chlorine dioxide case studies. Ozone Sci Eng 22:215-226

Shigematsu S, Al D, Sawoo O, Batéjat C, Matsuyama T, Leclercq I, Manuguerra JC (2014) Influenza A virus survival in water is influenced by the origin species of the host cell. Influ Other Respir Viruses 8:123-130

Sigstam T, Gannon G, Cascella M, Pecson BM, Wigginton KR, Kohn T (2013) Subtle differences in virus composition affect disinfection kinetics and mechanisms. Appl Environ Microbiol 79:3455-3467

Sigstam T, Rohatschek A, Zhong Q, Brennecke M, Kohn T (2014) On the cause of the tailing phenomenon during virus disinfection by chlorine dioxide. Water Res 48:82-89

Simonet J, Gantzer C (2006) Degradation of the poliovirus 1 genome by chlorine dioxide. J Appl Microbiol 100:862-870

Sobsey MD (1989) Inactivation of health-related microorganisms in water by disinfection processes. Water Sci Technol 21:179-195

Sorlini S, Gialdini F, Biasibetti M, Collivignarelli C (2014) Influence of drinking water treatments on chlorine dioxide consumption and chlorite/chlorate formation. Water Res 54:44-52

Stewart DJ, Napolitano MJ, Bakhmutovaalbert EV, Margerum DW (2008) Kinetics and mechanisms of chlorine dioxide oxidation of tryptophan. Inorg Chem 47:1639-1647
Tachikawa M, Saita K, Tezuka M (1993) Inactivation of poliovirus with chlorine dioxide. Eisei kagaku 39:572-576

Taylor GR, Butler M (1982) A comparison of the virucidal properties of chlorine, chlorine dioxide, bromine chloride and iodine. J Hyg $89: 321-328$

Thurston-Enriquez JA, Haas CN, Jacangelo J, Gerba CP (2003) Chlorine inactivation of adenovirus type 40 and feline calicivirus. Appl Environ Microbiol 69:3979-3985

Thurston-Enriquez JA, Haas CN, Jacangelo J, Gerba CP (2005) Inactivation of enteric adenovirus and feline calicivirus by chlorine dioxide. Appl Environ Microbiol 71:3100-3105

Wang XW et al (2005) Study on the resistance of severe acute respiratory syndrome-associated coronavirus. J Virol Methods 126:171-177

WHO (2011) Guidelines for drinking-water quality. WHO Chron 38:104-108

Wigginton KR, Boehm AB (2020) Environmental engineers and scientists have important roles to play in stemming outbreaks and pandemics caused by enveloped viruses. Environ Sci Technol 54:3736-3739

Wigginton KR, Pecson BM, Sigstam T, Bosshard F, Kohn T (2012) Virus inactivation mechanisms: impact of disinfectants on virus function and structural integrity. Environ Sci Technol 46:12069-12078

Wilson SC, Wu C, Andriychuk LA, Martin JM, Brasel TL, Jumper CA, Straus DC (2005) Effect of chlorine dioxide gas on fungi and mycotoxins associated with sick building syndrome. Appl Environ Microbiol 71:5399-5403

Winiecka-Krusnell J, Linder E (1998) Cysticidal effect of chlorine dioxide on Giardia intestinalis cysts. Acta Trop 70:369-372

Xue B et al (2013) Effects of chlorine and chlorine dioxide on human rotavirus infectivity and genome stability. Water Res 47:3329-3338

Yang ZY et al (2004) pH-dependent entry of severe acute respiratory syndrome coronavirus is mediated by the spike glycoprotein and enhanced by dendritic cell transfer through DC-SIGN. J Virol 78:5642-5650

Yang X, Guo W, Lee W (2013) Formation of disinfection byproducts upon chlorine dioxide preoxidation followed by chlorination or chloramination of natural organic matter. Chemosphere 91:1477-1485

Ye Y, Chang PH, Hartert J, Wigginton KR (2018) Reactivity of enveloped virus genome, proteins, and lipids with free chlorine and UV254. Environ Sci Technol 52:7698-7708

Zhong Q, Carratalà A, Ossola R, Bachmann V, Kohn T (2017) Crossresistance of UV- or chlorine dioxide-resistant echovirus 11 to other disinfectants. Front Microbiol 8:1928-1940

Zhong Y et al (2019) Disinfection byproducts and their toxicity in wastewater effluents treated by the mixing oxidant of $\mathrm{ClO}_{2} / \mathrm{Cl}_{2}$. Water Res 162:471-481

Zhu Z et al (2019) Chlorine dioxide inhibits the replication of porcine reproductive and respiratory syndrome virus by blocking viral attachment. Infect Genet Evol 67:78-87

Zoni R, Zanelli R, Riboldi E, Bigliardi L, Sansebastiano G (2007) Investigation on virucidal activity of chlorine dioxide. experimental data on feline calicivirus, HAV and Coxsackie B5. J Prev Med Hyg 48:91-99

Publisher's Note Springer Nature remains neutral with regard to jurisdictional claims in published maps and institutional affiliations. 